\title{
Multi-drug resistant pathogenic bacteria in the gut of young children in Bangladesh
}

(a) CrossMark

Shirajum Monira', Syeda Antara Shabnam', Sk. Imran Ali', Abdus Sadique ${ }^{1}$, Fatema-Tuz Johura', Kazi Zillur Rahman', Nur Haque Alam', Haruo Watanabe ${ }^{2}$ and Munirul Alam ${ }^{1 *}$

\begin{abstract}
Background: The gut of human harbors diverse commensal microbiota performing an array of beneficial role for the hosts. In the present study, the major commensal gut bacteria isolated by culturing methods from 15 children of moderate income families, aged between 10 and 24 months, were studied for their response to different antibiotics, and the molecular basis of drug resistance.

Results: Of 122 bacterial colonies primarily selected from Luria-Bertani agar, bacterial genera confirmed by analytical profile index (API) $20 \mathrm{E}^{\circledR}$ system included Escherichia as the predominant (52\%) organism, followed by Enterobacter (16\%), Pseudomonas (12\%), Klebsiella (6\%), Pantoea (6\%), Vibrio (3\%), and Citrobacter (3\%); while Aeromonas and Raoultella were identified as the infrequently occurring genera. An estimated 11 and $22 \%$ of the E. coli isolates carried virulence marker genes stx-2 and eae, respectively. Antimicrobial susceptibility assay revealed $78 \%$ of the gut bacteria to be multidrug resistant (MDR) with highest resistance to erythromycin (96\%), followed by ampicillin (63\%), tetracycline (59\%), azithromycin (53\%), sulfamethoxazole-trimethoprim (43\%), cefixime (39\%), and ceftriaxone (33\%). PCR assay results revealed $56 \%$ of the gut bacteria to possess gene cassette Class 1 integron; while $8,17.5$ and $6 \%$ of the strains carried tetracycline resistance-related genes tet $A$, tet $B$, and tet $D$, respectively. The macrolide (erythromycin and azithromycin) resistance marker genes $\mathrm{mphA}$, ereB, and ermB were found in 28,3 and $5 \%$ of bacterial isolates, respectively; while $26,12,17,32,7,4$ and $3 \%$ of the MDR bacterial isolates carried the extended spectrum $\beta$-lactamase (ESBL)-related genes e.g., bla $a_{\mathrm{TEM}}$, bla $a_{\mathrm{SH},}$, bla $a_{\mathrm{CMY}-9,}$, bla $a_{\mathrm{CTX}-\mathrm{M} 1}, b / a_{\mathrm{CTX}-\mathrm{M} 2}$, bla $a_{\mathrm{CMY}-2}$ and bla $a_{\mathrm{OXA}}$ respectively. Majority of the MDR gut bacteria harbored large plasmids [e.g., $140 \mathrm{MDa}(43 \%), 105 \mathrm{MDa}$ (30\%), $90 \mathrm{MDa}(14 \%)]$ carrying invasion and related antibiotic resistance marker genes.
\end{abstract}

Conclusions: Our results suggest gut of young Bangladeshi children to be an important reservoir for multi-drug resistant pathogenic bacteria carrying ESBL related genes.

Keywords: Children, Gut, Microbiota, Multidrug resistance, ESBL related genes

\section{Background}

The gut of human harbors diverse microbial community including 400-500 different species of bacteria performing an array of important metabolic functions for the host namely production of short-chain fatty acids and vitamins (vitamin $\mathrm{k}$ and biotin), nutrient absorption, and fighting against invading pathogens $[1,2]$. Diarrhea and

\footnotetext{
*Correspondence: munirul@icddrb.org

${ }^{1}$ International Center for Diarrheal Disease Research, Bangladesh (icddr,b), 68 Shaheed Tajuddin Ahmed Sarani, Mohakhali, Dhaka 1212, Bangladesh

Full list of author information is available at the end of the article
}

poor child health are longstanding problems for many developing countries where sanitation is poor and the source of safe drinking water is scarce. In Bangladesh, a child under 5 years of age frequently suffers from moderate to severe diarrhea, on an average 3-4 times a year [3]. The hospitalized patients suffering from severe diarrhea (cholera) undergo rehydration therapy and a 3 day course of effective antibiotic to shorten the hospitalization and to prevent the spread of infectious bacteria into the environment $[4,5]$. Although antibiotic therapy prevents people from death due to severe infection and related 
dehydration, the effect of antibiotics on the gut flora in acute diarrhea remains an important area to explore.

Our culture-independent metagenomic studies provided evidence that acute diarrhea (cholera) results in the expulsion of most of the commensal gut microbiota, and drug therapy allows the drug-resistant pathogenic microbiota to colonize the gut [7]. Our metagenomic studies also revealed that the members of the phyla Proteobacteria including pathogenic genera were predominant in the gut of malnourished children compared to their healthy counterparts [6]. In Bangladesh, infectious diseases due to multidrug resistant (MDR) bacteria are at rise, although the reservoir for such MDR bacteria is not well defined. This study, a follow up, was designed to analyze gut microbiota from 15 children aged between 10 and 24 months, who did not have immediate past history of diarrhea for last 2 months, and were from moderate income families living in moderate hygiene condition in Dhaka city. We confirmed the gut of children under 5 years of age as an important reservoir for MDR bacterial genera belonging to the family Enterobacteriaceae, which included surface water bacteria, including important human pathogens carrying major virulence plasmids and related genetic elements responsible for multidrug resistance.

\section{Methods}

\section{Study subjects}

This study was conducted in Dhaka city during February 2011-July 2012 on gut bacteria of 15 non-diarrheal children from moderate socioeconomic status. The age of the children ranged between 10 and 24 months and their weight for height was $>100 \%$ according to the National Centre for Health Statistics Median [8]. All children were residing in their home, without any sign of ailments, and none had any history of taking any antibiotics during the past 2 months. Their baseline characteristics are presented in Table 1. For sample collection, health workers visited the house-holds of the children to get mothers' consents and to demonstrate the sample collection procedure by providing them pots for stool collection. Fresh stool samples collected in the following morning were transferred to the laboratory maintaining cold chain.

\section{Enrichment, plating and identification of bacteria}

Stool samples were inoculated for enrichment in $3 \mathrm{ml}$ of Luria Broth (Difco, USA) using sterile cotton swabs and incubated overnight at $37^{\circ} \mathrm{C}$ in a shaking water bath. The enriched samples were diluted six folds and streaked onto Luria Agar (Difco, USA) plates; and the growth of the colonies were observed after overnight incubation at $37^{\circ} \mathrm{C}$. Twenty colonies of various morphological types (viz., size, shapes, elevation, opacity) representing
Table 1 Baseline characteristics of study children

\begin{tabular}{ll}
\hline Criteria & Healthy children $(\mathbf{n}=\mathbf{1 5})$ \\
\hline Age, month & $20.9 \pm 6.4$ \\
Weight, $\mathrm{kg}$ & $11.8 \pm 1.0$ \\
Height, $\mathrm{cm}$ & $74.9 \pm 2.9$ \\
Weight/height, \% & $114.5 \pm 5.9$ \\
Weight/age, \% & $101.3 \pm 3.1$ \\
Male/female & $9 / 6$ \\
Socio-economic status & Moderate \\
\hline
\end{tabular}

Values are expressed as mean \pm SD

bacterial community were randomly selected from each samples and identified by culturing over night in the Analytical Profile Index (API 20E ${ }^{\circledR}$ ) test kit (bioMerieux Inc., Hazelwood, MO).

\section{Antibiotic susceptibility testing}

Antimicrobial susceptibility assay of the bacterial strains was performed using agar disc diffusion assay method recommended by the Clinical and Laboratory Standards Institute [9]. Commercially available antimicrobial discs (Mast Diagnostics, U.K) of erythromycin $(15 \mu \mathrm{g})$, gentamicin $(10 \mu \mathrm{g})$, sulfamethoxazole-trimethoprim $(25 \mu \mathrm{g})$, tetracycline $(30 \mu \mathrm{g})$, ciprofloxacin $(5 \mu \mathrm{g})$, azithromycin $(15 \mu \mathrm{g})$, ampicillin $(10 \mu \mathrm{g})$, ceftriaxone $(30 \mu \mathrm{g})$, cefixime $(5 \mu \mathrm{g})$, and mecillinam $(10 \mu \mathrm{g})$ were placed on MuellerHinton agar (Bio-Rad) seeded with bacteria cultured in their early log phase, as previously described CLSI [9]. Following incubation, the plates were examined, and the inhibitory zone diameters for individual antimicrobial agents were measured and recorded as susceptible and resistant based on the breakpoints for respective antibiotic susceptibility of CLSI (CLSI 2010). Organisms resistant to 3 or more classes of antibiotics are designated as MDR. Zone diameter, breakpoints $(\mathrm{mm})$ : erythromycin $(15 \mu \mathrm{g}) \mathrm{S}-\mathrm{I}-\mathrm{R}$ : $>26,23-25,<2$; gentamicin $(10 \mu \mathrm{g})$ : $>15,13-14,<12$; sulfamethoxazole trimethoprim $(25 \mu \mathrm{g})$ : $>26,23-25,<22$; tetracycline $(30 \mu \mathrm{g}):>26$, 23-25, <22; ciprofloxacin $(5 \mu \mathrm{g})$ : $>21,15-20,<14$; ampicillin $(10 \mu \mathrm{g})$ : $>17,14-16,<13$; ceftriaxone $(30 \mu \mathrm{g}):>16$, $13-15,<12$; cefixime $(5 \mu \mathrm{g})$ : $>19,16-18,<15$; azithromycin $(15 \mu \mathrm{g})$ : $>18,14-17,<13$; mecillinam $(10 \mu \mathrm{g}):>15$, $12-14,<11$.

\section{Extraction of genomic DNA and plasmids from bacteria}

Genomic DNA was extracted from $3.0 \mathrm{ml}$ of cells cultured overnight in LB broth using alkaline lysis method followed by phenol-chloroform extraction, as described elsewhere [10]. The eluted DNA was stored at $-20^{\circ} \mathrm{C}$.

Plasmid DNA was extracted according to the conventional simplified alkaline lysis method [11] and afterwards 
separated by horizontal electrophoresis in $0.8 \%$ agarose gels in a Tris-borate EDTA buffer at room temperature at $100 \mathrm{~V}(50 \mathrm{~mA})$ for $3 \mathrm{~h}$. Thirty microliters of plasmid DNA solution were mixed with $3 \mu \mathrm{l}$ of tracking dye and was loaded into the individual well of the gel. The gel was stained with ethidium bromide $(0.1 \mathrm{ng} / \mathrm{ml})$ for $30 \mathrm{~min}$ at room temperature. DNA bands were visualized and photographed using Gel Documentation with UV Trans illuminator. The molecular weight of the unknown plasmid DNA was determined on the basis of its mobility through agarose gel and was compared with the mobility of the known molecular weight plasmids present in strains of $E$. coli $\mathrm{PDK}-9$ of sizes 140, 105, 2.7 and 2.1 MDa.

\section{PCR detection of genes associated with virulence and antibiotic resistance of $E$. coli}

Escherichia coli strains isolated and confirmed by API $20 \mathrm{E}^{\circledR}$ were screened by PCR for the detection of virulence genes namely $s t x 1, s t x-2, l t$, and eae by following methods as described elsewhere [12]. The gut bacteria isolated in present study were screened for macrolide resistance marker genes such as $m p h \mathrm{~A}$, ere $\mathrm{B}$ and erm $\mathrm{B}$ [13]; tetracycline resistance genes e.g., tet $\mathrm{A}$, tet $\mathrm{B}$, and tet $\mathrm{D}$ [14]; $\beta$-lactam resistance gene in enteric bacteria e.g., bla $a_{\mathrm{TEM}}, b l a_{\mathrm{SHV}}, b l a_{\mathrm{OXA}}, b l a_{\mathrm{CMY}-9}, b l a_{\mathrm{CMY}-2}, b l a_{\mathrm{CTX}-}$ ${ }_{\mathrm{M} 1}$, and $b l a_{\mathrm{CTX}-\mathrm{M} 2}[14,15]$. The distribution of integrons in multi-drug resistant bacteria was determined by PCR primer targeted against the conserved regions of the integrin-encoded integrase genes, intl-1 [16]. SXT is a family of conjugative-transposon-like mobile genetic elements encoding multiple antibiotic resistance genes. Multi-drug resistant bacteria were analyzed for the presence of $S X T$ related genes by PCR targeting the integrase gene (int) of the SXT [17]. The PCR primers used in this study are listed in Table 2.

\section{Results}

Isolation and identification of gut bacteria

Of 122 bacterial colonies primarily selected from the culture plates, nine different bacterial genera were identified by conventional microbiological culture methods coupled with the use of analytical profile index (API) $20 \mathrm{E}^{\circledR}$ system. As shown in Table 3, bacteria isolated from the gut of young children included important pathogenic bacteria along with the ones that are widely known as commensals, and were predominated by the members of the family Enterobacteriaceae. Escherichia was identified to be the dominant bacterial genera accounting for $52 \%$, followed by Enterobacter (16\%), Pseudomonas (12\%), Klebsiella (6\%), Pantoea (6\%), Vibrio (3\%), and Citrobacter (3\%); while Aeromonas and Raoultella were also identified, but as infrequently occurring genera. Replicates of the bacterial colonies representing each of the genera were collected and stored in T1N1 soft agar (both at room temperature and $-80^{\circ} \mathrm{C}$ ) for further use.

\section{Antimicrobial susceptibility assay of gut bacteria}

Results of antimicrobial susceptibility assay by disc diffusion method revealed $78 \%$ of the gut bacteria to be resistant to multiple antimicrobial drugs (Table 3), and were thus multidrug resistant (MDR). Among them $E$. coli was the predominant MDR (55\%) bacterium followed by Enterobacter spp. (16\%), Pseudomonas spp. (13\%), Klebsiella spp. (5\%), Pantoea spp. (4\%), Vibrio spp. (1\%), Citrobacter spp. (4\%), Aeromonas hydrophila (1\%) and Raoultella terrigena (1\%).

Ca. $96 \%$ of the commensal bacteria occurring in the gut of children were resistant to erythromycin, followed by ampicillin (63\%), tetracycline (59\%), azithromycin (53\%), sulfamethoxazole-trimethoprim (43\%), cefixime (39\%), and ceftriaxone (33\%) (Table 3).

Since $E$. coli was the predominant MDR bacterial lineage (54\%) found in the gut of young children, this bacterium was investigated for detailed drug resistance profile. Overall results revealed 3\% of the MDR E. coli to be resistant to 9 of the 10 antimicrobial agents tested. E. coli strains were highly resistant to commonly used antibiotics e.g., erythromycin (97\%), followed by tetracycline (71\%), ampicillin (67\%), azithromycin (54\%), and cefixime (44\%) (Table 3).

As shown in Table 3, Enterobacter spp. constituted the second most largest group of bacteria in the gut of young children comprising E. cloacae, E. cancerogenus, and E. sakazakii. Results revealed 90, 53, and $42 \%$ of the Enterobacter isolates to be resistant to ampicillin, ceftriaxone, and cefixime, respectively.

\section{Polymerase chain reaction (PCR) for detection of virulence and related marker genes}

Polymerase chain reaction assay results revealed $56 \%$ of the overall gut bacteria to harbor gene cassettes namely Class 1 integron. PCR assays also revealed 11 and 22\% of the $E$. coli isolates to harbor important virulence and related marker genes such as $s t x-2$ and eae, respectively. None of the isolates was positive for stxl, and lt. E. coli isolates showing resistance to tetracycline carried the resistance related genes namely tet $\mathrm{A}(8 \% ; 5 / 63)$, tet $\mathrm{B}$ $(17.5 \% ; 11 / 63)$, and tetD 6.0\% (4/63). None of the other bacteria isolated from the gut of young children had any of these genes.

Resistance markers against macrolide antibiotics (erythromycin and azithromycin) e.g., $m p h \mathrm{~A}$, ere $\mathrm{B}$ and ermB were found in $28 \%(34 / 122), 3 \%(3 / 122)$, and $5 \%$ (6/122) different gut bacterial isolates, respectively. The gut bacterial isolates were positive for extended spectrum betalactamase-related genes such as, $b l a_{\mathrm{TEM}}(26 \%$; $32 / 122)$, bla $_{\mathrm{SHV}}(12 \% ; 14 / 122)$, bla $_{\mathrm{CMY}-9}(17 \% ; 21 / 122)$, 
Table 2 PCR primers for screening virulence and antibiotic resistance genes in bacteria isolated from the gut of healthy children in Bangladesh

\begin{tabular}{|c|c|c|c|c|}
\hline Primer & Primer sequence $\left(5^{\prime} \rightarrow 3^{\prime}\right)$ & Target & Amplicon size (bp) & References \\
\hline Stx2f & GGCACTGTCTGAAACTGCTCC & $s t x_{2}$ & 225 & [12] \\
\hline Stx2r & TCGCCAGTTATCTGACATTCTG & & & \\
\hline eae1 & CTGAACGGCGATTACGCGAA & eae & 917 & {$[12]$} \\
\hline eae2 & CCAGACGATACGATCCAG & & & \\
\hline INT-1U & GTTCGGTCAAGGTTCTG & int/1 & 923 & [16] \\
\hline INT-1D & GCCAACTTTCAGCACATG & & & \\
\hline $\operatorname{mphA}(\mathrm{F})$ & GTGAGGAGGAGCTTCGCGAG & mphA & 403 & [13] \\
\hline $\operatorname{mphA}(\mathrm{R})$ & TGCCGCAGGACTCGGAGGTC & & & \\
\hline $\operatorname{ereB}(\mathrm{F})$ & TTGGAGATACCCAGATTGTAG & ereB & 537 & [13] \\
\hline $\operatorname{ereB}(\mathrm{R})$ & GAGCCATAGCTTCAACGC & & & \\
\hline $\operatorname{ermB}(F)$ & GAAAAAGTACTCAACCAAATA & ermB & 639 & [13] \\
\hline $\operatorname{ermB}(\mathrm{R})$ & AATTTAAGTACCGTTACT & & & \\
\hline INT1 & GCTGGATAGGTTAAGGGCGG & Sxt-integrase & 592 & {$[17]$} \\
\hline INT2 & CTCTATGGGCACTGTCCACATTG & & & \\
\hline $\operatorname{TEM}(F)$ & ATTCTTGAAGACGAAAGGGC & $b l a_{\text {TEM }}$ & 1150 & [14] \\
\hline TEM(R) & ACGCTCAGTGGAACGAAAAC & & & \\
\hline OXA-F & ACACAATACATATCAACTTCGC & $B l a_{\mathrm{OXA}}$ & 813 & [14] \\
\hline OXA-R & AGTGTGTTTAGAATGGTGATC & & & \\
\hline SHV-F & CACTCAAGGATGTATTGTG & $b l a_{\mathrm{SHV}}$ & 885 & [14] \\
\hline SHV-R & TTAGCGTTGCCAGTGCTCG & & & \\
\hline CMY-9(F) & TCAGCGAGCAGACCCTGTTC & $b / a_{\mathrm{CMY}-9}$ & 874 & {$[15]$} \\
\hline CMY-9(R) & CTGGCCGGGATGGGATAGTT & & & \\
\hline CTX-M1(F) & AACCGTCACGCTGTTGTTAG & $b l a_{\text {CTX-M1 }}$ & 766 & {$[15]$} \\
\hline CTX-M1(R) & TTGAGGCTGGGTGAAGTAAG & & & \\
\hline CTX-M2(F) & GGCGTTGCGCTGATTAACAC & $b^{b} a_{\mathrm{CTX}-\mathrm{M} 2}$ & 486 & [15] \\
\hline CTX-M2(R) & TTGCCCTTAAGCCACGTCAC & & & \\
\hline TetA (F) & GTAATTCTGAGCACTGTCGC & tetA & 937 & [14] \\
\hline TetA (R) & CTGCCTGGACAACATTGCTT & & & \\
\hline TetB (F) & CTCAGTATTCCAAGCCTTTG & tetB & 416 & [14] \\
\hline TetB (R) & CTAAGCACTTGTCTCCTGTT & & & \\
\hline TetD (F) & ATTACACTGCTGGACGCGAT & tetD & 1104 & [14] \\
\hline TetD (R) & CTGATCAGCAGACAGATTGC & & & \\
\hline
\end{tabular}

bla $a_{\mathrm{CTX}-\mathrm{M} 1}(32 \% ; 39 / 122), b l a_{\mathrm{CTX}} \mathrm{M} 2(7 \% ; 8 / 122), b l a_{\mathrm{CMY}-2}$ $(4 \% ; 5 / 122)$, and $b l a_{O X A}(3 \% ; 4 / 122)$ conferring resistance to $\beta$-lactam antibiotics.

\section{Detection of virulence and related large plasmids}

Results revealed that majority of the MDR bacterial isolates from the gut of children harbored large plasmids e.g., $140 \mathrm{MDa}$ (43\%), $105 \mathrm{MDa}$ (30\%), and $90 \mathrm{MDa}(14 \%)$ carrying invasion and related antibiotic resistance marker genes (Fig. 1).

\section{Discussions}

Data presented in this study coupled with the data reported earlier in our culture-independent metagenomic studies provide important insights into the prevalence of MDR bacterial genera of the family Enterobacteriaceae in the gut of young children in Bangladesh. Our results appear concordant as drug resistant bacteria were reported from the gut of healthy children elsewhere [18, 19]. In Bangladesh, children suffer from frequent diarrhea and their gut can serve as an important reservoir for pathogenic bacteria of the family enterobacteriaceae, including genera that are naturally occurring in the aquatic environments [6]. The results of this culture-based gut microbiota study appear in agreement with the data obtained in our immediate past cultureindependent metagenomic study showing the presence in the gut of pathogenic bacteria belonging to the family enterobacteriaceae, which included pathogenic bacteria occurring naturally in the aquatic environments [6]. Our 
Table 3 Isolation of multi-drug resistant bacteria of the family Enterobacteriaceae, including the potential pathogens occurring in the gut of young children in Bangladesh

\begin{tabular}{|c|c|c|c|c|c|c|c|c|c|c|c|c|c|}
\hline \multirow[t]{2}{*}{ Sl.\# } & \multirow[t]{2}{*}{ Bacteria } & \multirow[t]{2}{*}{ Total } & \multicolumn{11}{|c|}{ Number of antibiotic resistant bacteria (\%) } \\
\hline & & & MDR & $\mathrm{E}$ & $\mathrm{CN}$ & SXT & TE & CIP & AMP & CRO & CFM & AZM & MEL \\
\hline 1 & E. coli & 63 & 52 & $61(97)$ & $9(14)$ & $26(41)$ & $45(71)$ & $16(25)$ & $42(67)$ & $18(29)$ & $28(44)$ & $34(54)$ & $7(11)$ \\
\hline 2 & Enterobacter spp. & 19 & 15 & $19(100)$ & $2(11)$ & $13(68)$ & $12(63)$ & 0 & $17(90)$ & $10(53)$ & $9(47)$ & $8(42)$ & $1(5)$ \\
\hline 3 & Pseudomonas spp. & 15 & 12 & $15(100)$ & 0 & 0 & $1(7)$ & $2(13)$ & $13(87)$ & $4(27)$ & $2(13)$ & $12(63)$ & $9(60)$ \\
\hline 4 & Klebsiella spp. & 7 & 5 & $7(100)$ & 0 & $3(43)$ & $3(43)$ & 0 & $6(86)$ & 0 & $1(14)$ & $3(43)$ & $2(29)$ \\
\hline 5 & Pantoea spp. & 7 & 4 & $7(100)$ & $1(14)$ & $4(57)$ & $5(71)$ & 0 & $5(71)$ & $3(43)$ & $3(43)$ & $3(43)$ & $1(14)$ \\
\hline 6 & Vibrio spp. & 4 & 1 & $2(50)$ & 0 & $1(25)$ & $1(25)$ & $1(25)$ & $2(40)$ & $1(25)$ & $1(25)$ & $1(25)$ & 0 \\
\hline 7 & Citrobacter spp. & 4 & 4 & $3(75)$ & $2(50)$ & $4(100)$ & $4(100)$ & $4(100)$ & $3(75)$ & $2(50)$ & $3(75)$ & $3(75)$ & $1(25)$ \\
\hline 8 & Aeromonas hydrophila gr. 1 & 2 & 1 & $2(100)$ & 0 & $1(50)$ & $1(50)$ & 0 & 0 & $2(100)$ & $1(50)$ & 0 & 0 \\
\hline 9 & Raoultella terrigena & 1 & 1 & $1(100)$ & 0 & 0 & 0 & 0 & 0 & 0 & 0 & $1(100)$ & $1(100)$ \\
\hline 10 & Total & 122 & 95 (78) & $117(96)$ & $14(11)$ & $52(43)$ & $72(59)$ & $23(19)$ & $77(63)$ & $40(33)$ & $48(39)$ & $65(53)$ & $22(18)$ \\
\hline
\end{tabular}

E erythromycin, $15 \mu \mathrm{g}$; CN gentamicin, $10 \mu \mathrm{g}$; SXT trimethoprim sulfamethoxazole, $25 \mu \mathrm{g} ;$ TE tetracycline, $30 \mu \mathrm{g}$; CIP ciprofloxacin, $5 \mu \mathrm{g} ; A M P$ ampicillin, $10 \mu \mathrm{g} ; C R O$ ceftriaxone, $30 \mu \mathrm{g}$; CFM cefixime, $5 \mu \mathrm{g}$; AZM azithromycin, 15; MEL mecillinam, $10 \mu \mathrm{g}$

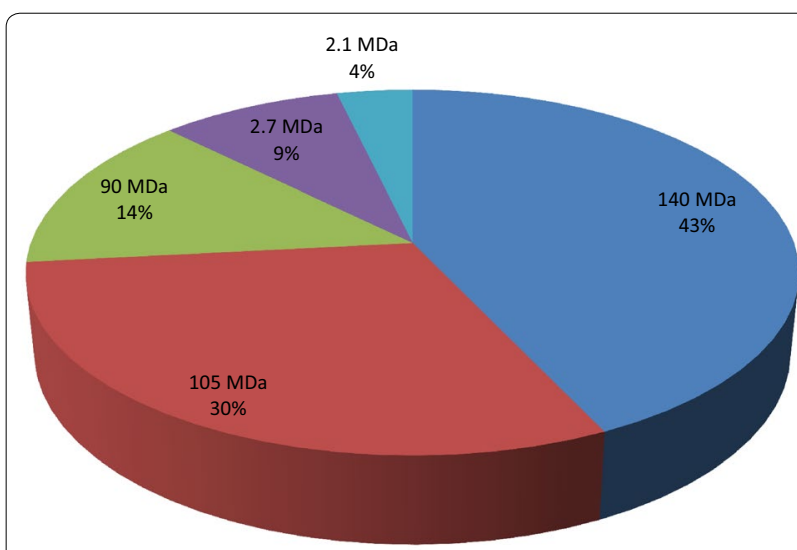

Fig. 1 Distribution of plasmids isolated from 122 bacteria identified from fecal samples of 15 young children of moderate income families living in moderate hygiene condition in Dhaka city

subsequent culture-independent metagenomic studies also showed that the antimicrobial therapy in acute diarrhea results in dysbiosis, and selectively allows only the antibiotic resistant microbiota to enrich and settle in the gut of children [7]. As the course of medication ended, the prevalent antibiotic-guarded community declined, but did not disappear completely as floral restoration followed up to day 28 of our observation [7]. Thus, frequent diarrhea and related multiple doses of antibiotics likely enrich multi-drug resistant bacteria in the gut, as reflected by the observed predominance of extendedspectrum beta-lactamase (ESBL) positive Gram-negative bacterial genera including the recognized enteric and opportunistic pathogens in the gut of young children in Bangladesh. Thus, the data presented in this study might provide a basis for the widespread growth stunting related to the gut floral immaturity, as has been proposed for Bangladeshi children [20] reaching their adulthood as malnourished.

Escherichia coli was the most abundant bacteria as confirmed by our culture-based analysis of the gut microbiota of young children in Bangladesh. The most striking finding may be that $11 \%$ of the E. coli occurring in the gut of young children had genes encoding shiga toxin (stx)2 , and $22 \%$ possessed eae encoding an intimin adherence protein responsible for hemorrhagic colitis and hemolytic uremic syndrome caused by enterohemorrhagic $E$. coli (EHEC). Besides, a great majority (83\%) of the E. coli isolated from the gut of children were MDR in Bangladesh. Drug resistant E. coli was reported from healthy children of USA, Venezuela, and China [21-23]; however, to our knowledge, MDR gut bacteria carrying EHEC genes namely $s t x-2$ and eae are unique in the present study, which indicate a potential health risk for the young children of Bangladesh.

Enterobacter cloacae, a commensal gut bacteria occurring widely in the environment, has the ability to cause opportunistic infections in human $[24,25]$. The abundance of Enterobacter spp., namely E. cloacae and $E$. cancerogenus as commensal flora of the gut of young children might reflect the potential health risks related to these opportunistic pathogens. E. cloacae was shown to develop resistance to cephalosporins related to high frequency mutation in the resistance genes of extendedspectrum cephalosporins and ampicillin [25-27]. In concurrence, almost half of the commensal Enterobacter spp. isolated from gut of young children were resistant to cephalosporin antibiotics (e.g., ceftriaxone and cefixime) in Bangladesh. 
Environmental enteropathy (EE), also known as tropical enteropathy or environmental enteric dysfunction, is a condition of frequent intestinal infections [28]. There may be rare or no acute symptoms, but the chronic problem associated with the $\mathrm{EE}$ is the mal absorption of nutrients, which can lead to malnutrition and growth stunting in children [28]. In Dhaka city, municipal supply water was shown have multiple infectious agents, including bacteria [29]. The observed prevalence of the pathogenic member of the family Enterobacteriaceae in the gut of young children might reflect widespread environmental enteropathy in Dhaka city. Although boiling is an effective way to kill water-borne pathogens, this is often not practical due to poor or no access to fuel. A recent study revealed possible post-collection contamination of water at the household level, as the pathogen counts were much higher in the household drinking water than that of the supply water [29]. Such pathogenic bacteria causing frequent infections (3-5 episodes of diarrhea/year) can eventually settle down in the gut as a commensal microbiota [6], as we observed in the gut of children living in Dhaka city. This is plausible as the type of microbiota in the gut of cohort of European and rural African children was determined by their regular foods [30].

The observed multi-drug resistance in gut microbiota of young children of Bangladesh appeared concordant with results from studies reporting MDR bacteria from healthy fecal samples of adults [31-33] and children [18, $19,21,22]$ from other countries of the world. Plasmids are known to carry and transmit drug resistance and related genes in bacteria [33, 34]. A $140 \mathrm{MDa}$ plasmid is known to be associated with the invasiveness of Shigella flexneri [35]. In the present study, a significant proportion $(48 \%)$ of the gut bacteria of young children harbored a $140 \mathrm{MDa}$ plasmids. To the best of our knowledge this is the first report of the presence of such major plasmids in bacteria other than Shigellae occurring in the gut of young children, which can transfer resistance and related genes horizontally across different genera.

The gene cassettes such as classes 1 and 2 integrons are responsible for multidrug resistance in Gram-negative bacteria [14]. Class 1 integron was found from 57\% $(39 / 68)$ of the E. coli occurring in the gut of young children in Dhaka city. Our results appear in agreement, as intl-1 was reported from as high as $71 \%$ of MDR E. coli isolated from human, animal, and food in Spain [14]. The observed presence of tetracycline resistance-related genes tet $\mathrm{A}$, tet $\mathrm{B}$, and tet $\mathrm{D}$ encoding efflux proteins in the commensal E. coli was in agreement in the present study, as tetracycline resistant strains have been reported from the gut of infants in a previously study conducted elsewhere [36]. Tetracycline resistance-related genes tet $\mathrm{A}$, tet $\mathrm{B}$, and tet $\mathrm{D}$ were found only from the MDR $E$. coli strains, but not from any other commensal bacteria occurring in the gut of young children in Bangladesh. Our results appear in agreement as tet $\mathrm{A}$ and tet $\mathrm{B}$ were present in MDR E. coli isolated from human, animal, and food in Spain, but all carried a wide variety of other antibiotic resistance markers [14].

Bacteria producing enzymes beta-lactamases ( $\beta$-lactamases; also known as penicillinase) can degrade $\beta$-lactam antibiotics such as penicillins, cephamycins, and carbapenems (ertapenem), but rarely carbapenems, are MDR. The emergence of $\beta$-lactam resistance in Enterobacteriaceae is related primarily to the production of novel enzymes such as TEM-, SHV-, and OXA-type $\beta$-lactamases. Ampicillin-resistant $\left(\mathrm{AMP}^{\mathrm{r}}\right)$ E. coli isolated from foods, fecal samples of human, and healthy animals were shown to harbor bla-TEM-type $\beta$-lactamase [37]. In this study, majority (91\%) of the E. coli isolated from the gut of young children harbored bla- $T E M$ type $\beta$-lactamases in Bangladesh. Although the remaining $E$. coli isolates possessed $b l a_{\mathrm{OXA}}$ in our study, this is a clear indication of the proliferation of ESBLs producing bacteria among the commensal gut bacteria of young children, which is alarming from public health standpoint. The OXA-type $\beta$-lactamases were reported earlier in 2008 from clinical samples in Swedish hospital [38]. Previously, E. coli isolated from fecal samples of domestic animals, retail ground meats, and urinary samples were shown to carry and spread $b l a_{\mathrm{CMY}-2}$ in southern Taiwan [39]. In the present study, two each of Pantoea spp., E. cloacae, and one E. cancerogenus possessed $b l a_{\mathrm{CMY}-2}$. Bla $a_{\mathrm{CMY}-9}$ was identified as a novel plasmid mediated cephalosporinase in E. coli isolated from clinical samples in Japan [40]. Our results reveal $16 \%(20 / 122)$ of the bacteria occurring in the gut of young children possessed $b l a_{\mathrm{CMY}-9}$ gene. In addition, six Klebsiella spp. isolated in the present study from the gut of young children harbored the $b l a_{\mathrm{SHV}}$ gene responsible for ESBL activity in Klebsiella spp. [41].

In our previous study in Bangladesh, we have documented that acute diarrhea expels the gut flora while antibiotic provision for the hospitalized diarrhea patients selectively allows only the MDR bacteria belonging to enterobacteriaceae to be restored in the gut of children [6]. The observed prevalence of pathogenic bacteria carrying a wide variety of drug resistance marker genes, especially the extended spectrum beta-lactamase (ESBL) suggests the gut of young (under five years) children to be an important reservoir for MDR-related genes. This is suggestive of an apparent havoc, which will make the clinical management of diarrhea and other opportunistic bacterial infections, especially in severely malnourished and immunocompromised children very challenging. It is therefore evident prudent that more children will suffer from diarrhea due to MDR bacteria in Bangladesh, a 
densely populated country where hygiene level is poor and the dearth of safe drinking water will invite more untreatable diseases than ever before.

\section{Authors' contributions}

MA conceived the study. SM designed and carried out the study involving SAS, SKIA, AS, FTJ, and KZR. MA, SM, HW, and NHA were involved in the overall study in its implementation, data analysis, and manuscript writing. All authors read and approved the final manuscript.

\section{Author details}

${ }^{1}$ International Center for Diarrheal Disease Research, Bangladesh (icddr,b), 68 Shaheed Tajuddin Ahmed Sarani, Mohakhali, Dhaka 1212, Bangladesh.

${ }^{2}$ National Institute of Infectious Diseases, Tokyo, Japan.

\section{Acknowledgements}

icddr,b acknowledges the commitment of NIID to its research efforts. MA Acknowledges the support of Richard Bradley Sack of the Johns Hopkins University, USA. icddr,b acknowledges with gratitude the Governments of Bangladesh, Canada, Sweden, and the UK for providing core/unrestricted support.

\section{Competing interests}

The authors declare that they have no competing interests.

\section{Availability of data and materials}

Data sharing not applicable to this article.

\section{Declaration}

This research study was approved by the icddr,b institutional review board. Prior informed consent was obtained from parents or legal guardians of the children who participated in this study.

This study was presented in the 49th US-Japan cholera panel meeting held in 2015 in Gainesville, Florida, USA.

\section{Funding}

This research was partially supported by the National Institute of Infectious Diseases (NIID), Japan and icddr,b.

\section{Publisher's Note}

Springer Nature remains neutral with regard to jurisdictional claims in published maps and institutional affiliations.

Received: 9 January 2017 Accepted: 10 April 2017

Published online: 20 April 2017

\section{References}

1. Ramakrishna BS. The normal bacterial flora of the human intestine and its regulation. J Clin Gastroenterol. 2007;41:S2-6.

2. Ann M, O'Hara FS. The gut flora as a forgotten organ. EMBO Rep. 2006;6:688-93.

3. Bangladesh Demographic and Health Survey, 2014. http://www.niport. gov.bd/wp-content/uploads/publication/1432536472-BDHS2014KIR.pdf. Accessed 4 Dec 2016

4. Handbook of Integrated Management of Childhood IIIness. 2005. Reference Guide, Appendix 3. WHO/UNICEF.

5. WHO. Guideline: Updates on the management of severe acute malnutrition in infants and children. Geneva: World Health Organization; 2013. http://www.who.int/nutrition/publications/guidelines/updates_management SAM infantandchildren/en/. Accessed 4 Dec 2016.

6. Monira S, Nakamura S, Gotoh K, Izutsu K, Watanabe H, Alam NH, Endtz HP, Cravioto A, Ali SI, Nakaya T, et al. Gut microbiota of healthy and malnourished children in bangladesh. Front Microbiol. 2011;2:228.

7. Monira S, Nakamura S, Gotoh K, Izutsu K, Watanabe H, Alam NH, Nakaya T, Horii T, Ali SI, lida T, Alam M. Metagenomic profile of gut microbiota in children during cholera and recovery. Gut Pathog. 2013;5:1.
8. Measuring Change in Nutritional Status. Guide lines for Assessing the Nutritional Impact of Supplementary Feeding Programmes for Vulnerable Groups. Geneva: World Health Organization; 1983.

9. CLSI. Performance standards for antimicrobial susceptibility testing: twentieth informational supplement. Wayne: CLSI; 2010.

10. Chowdhury NR, Chakraborty S, Ramamurthy T, Nishibuchi M, Yamasaki S, Takeda Y, et al. Molecular evidence of clonal Vibrio parahaemolyticus pandemic strains. Emerg Infect Dis. 2000;6:631-6.

11. Kado Cl, Liu ST. Rapid procedure for detection and isolation of large and small plasmids. J Bacteriol. 1981;145:1365-73.

12. Khan A, Das SC, Ramamurthy T, et al. Antibiotic resistance, virulence gene, and molecular profiles of Shiga toxin-producing Escherichia coli isolates from diverse sources in Calcutta, India. J Clin Microbiol. 2002;40:2009-15.

13. Nguyen MCP, Woerther P-L, Bouvet $M$, Andremont $A$, Leclercq $R$, Cannu A Escherichia coli as reservoir for macrolide resistance genes. Emerg Infect Dis. 2009:15:1648-50.

14. Saenz Y, Brinas L, Dominguez E, Ruiz J, Zarazaga M, Vila J, Torres C. Mechanisms of resistance in multiple-antibiotic-resistant Escherichia coli strains of human, animal, and food origins. Antimicrob Agents Chemother 2004:48:3996-4001.

15. Chen S, Zhao S, White DG, Schroeder CM, Lu R, Yang H, McDermott PF, Ayers S, Meng J. Characterization of multiple-antimicrobial-resistant Salmonella serovars isolated from retail meats. Appl Environ Microbiol. 2004;70(1):1.

16. Zhang H, Shi L, Li L, Guo S, Zhang X, Yamasaki S, Miyoshi S, Shinoda S. Identification and characterization of class 1 integron resistance gene cassettes among Salmonella strains isolated from healthy humans in China. Microbial Immunol. 2004;48(9):639-45.

17. Hochhut B, Lotfi Y, Mazel D, Faruque SM, Woodgate R, Waldor MK Molecular analysis of antibiotic resistance gene clusters in Vibrio cholerae 0139 and 01 SXT constins. Antimicrob Agents Chemother. 2001;45(11):2991-3000

18. Calva JJ, Sifuentes-Osornio J, Cerón C. Antimicrobial resistance in fecal flora: longitudinal community-based surveillance of children from urban mexico. Antimicrob Agents Chemother. 1996:40:1699-702.

19. Millar MR, Walsh TR, Linton CJ, Zhang S, Leeming JP, Bennett PM, The ALSPAC Study Team. Carriage of antibiotic-resistant bacteria by healthy children. J Antimicrob Chemother. 2001;47:605-10.

20. Subramanian S, Huq S, Yatsunenko T, Haque R, Mahfuz M, Alam MA Benezra A, DeStefano J, Meier MF, Muegge BD, et al. Persistent gut microbiota immaturity in malnourished Bangladeshi children. Nature. 2014:510:417-21.

21. Lester SC, Pilar M, Wang F, Schael IP, Jiang H, O'Brien TF. The Carriage of Escherichia coli resistant to antimicrobial agents by healthy children in boston, in Caracas, Venezuela, and in Qin Pu, China. NEJM. 1990;323:285-9.

22. Barreto A, Guimaraes B, Radhouani H, et al. Detection of antibiotic resistant E. coli and Enterococcus spp. in healthy growing children in Portugal. J Basic Microbiol. 2009:49:503-12.

23. Jannine KB, Pinyon JL, Anantham S, Hall RM. Commensal Escherichia coll of healthy humans: a reservoir for antibiotic-resistance determinants. J Med Microbiol. 2010;59:1331-9.

24. Gaston MA. Enterobacter: an emerging nosocomial pathogen. J Hosp Infect. 1988;11:197-208

25. Keller RE, Pedroso MZ, Ritchmann R, Silva RM. Occurrence of virulence-associated properties in Enterobacter cloacae. Infect Immun. 1998:66:645-9.

26. Sanders CC, Sanders WE. Emergence of resistance during therapy with the newer $\beta$-lactam antibiotics: role of inducible $\beta$-lactamase and implications for the future. Rev Infect Dis. 1983:5:639-48.

27. Then RL. Ability of newer beta-lactam antibiotics to induce betalactamase production in Enterobacter cloacae. Eur J Clin Microbiol. 1987;6:451-5

28. Korpe PS, Petri WA Jr. Environmental enteropathy: critical implications of a poorly understood condition. Trends Mol Med. 2012;18(6):328-36.

29. Mondal D, Ganguli B, Roy SS, Halder B, Banerjee N, Banerjee M, Samanta M, Giri AK, Polya DA. Diarrhoeal health risks attributable to water-bornepathogens in arsenic-mitigated drinking water in West Bengal are largely independent of the microbiological quality of the supplied water. Water. 2014:6:1100-17. doi:10.3390/w6051100. 
30. De Filippo C, Cavalieri D, Di Paola M, Ramazzotti M, Poullet JB, Massart S, Collini S, Pieraccini G, Lionetti P. Impact of diet in shaping gut microbiota revealed by a comparative study in children from Europe and rural Africa. Proc Natl Acad Sci USA. 2010;107:14691-6.

31. London N, Nijsten R, Bogaard AVD, Stobberingh E. Carriage of antibioticresistant Escherichia coli by healthy volunteers during a 15-week period. Infection. 1994;22:187-92.

32. Nys S, Okeke IN, Kariuki S, Dinant GJ, Driessen C, Stobberingh EE. Antibiotic resistance of faecal Escherichia coli from healthy volunteers from eight developing countries. J Antimicrob Chemoth. 2004;54:952-5.

33. Poirel L, Kieffer N, Liassine N, Nordman P. Plasmid-mediated carbapenem and colistin resistance in a clinical isolate of Escherichia coli. Lancet Infect Dis. 2016;16(3):281. doi:10.1016/S1473-3099(16)00006-2.

34. Strahilevitz J, Jacoby GA, Hooper DC, Robicsek A. Plasmid-mediated quinolone resistance: a multifaceted threat. Clin Microbiol Rev. 2009;22(4):664-89.

35. Sasakawa C, Kamata K, Sakai T, Murayama SY, Makino S, Osikawa MI. Molecular alteration of the 140-megadalton plasmid associated with loss of virulence and Congo red binding activity in Shigella flexneri. Infect Immun. 1986:51:470-5

36. Karami N, Nowrouzian F, Adlerberth I, Wold AE. Tetracycline resistance in Escherichia coli and persistence in the infantile colonic microbiota. Antimicrob Agents Chemother. 2006;50:156-61.
37. Brinas L, Zarazaga M, Saenz Y, Ruiz-Larrea F, Torres C. Beta-lactamases in ampicillin-resistant Escherichia coli isolates from foods, humans, and healthy animals. Antimicrob Agents Chemother. 2002;46:3156-63.

38. Fang $\mathrm{H}$, Ataker F, Hedin G, Dornbusch K. Molecular epidemiology of extended-spectrum beta-lactamases among Escherichia coli isolates collected in a Swedish hospital and its associated health care facilities from 2001 to 2006. J Clin Microbiol. 2008;46:707-12.

39. Yan JJ, Hong CY, Ko WC, Chen YJ, Tsai SH, Chuang CL, Wu JJ. Dissemination of blaCMY-2 among Escherichia coli isolates from food animals, retail ground meats, and humans in southern Taiwan. Antimicrob Agents Chemother. 2004;48:1353-6.

40. Doi Y, Shibata N, Shibayama K, et al. Characterization of a novel plasmidmediated cephalosporinase (CMY-9) and its genetic environment in an Escherichia coli clinical isolate. Antimicrob Agents Chemother. 2002;46:2427-34.

41. Jones LA, Mclver CJ, Kim MJ, Rawlinson WD, White PA. The aadB gene cassette is associated with blaSHV genes in Klebsiella species producing extended-spectrum beta-lactamases. Antimicrob Agents Chemother. 2005;49:794-7.

\section{Submit your next manuscript to BioMed Central and we will help you at every step:}

- We accept pre-submission inquiries

- Our selector tool helps you to find the most relevant journal

- We provide round the clock customer support

- Convenient online submission

- Thorough peer review

- Inclusion in PubMed and all major indexing services

- Maximum visibility for your research

Submit your manuscript at www.biomedcentral.com/submit 